\title{
Partial purification and properties of cyclodextrin glycosiltransferase (CGTase) from alkalophilic Bacillus species
}

\author{
Marlene M Martínez Mora ${ }^{1}$, Karel Hernández Sánchez ${ }^{1}$, Reynaldo Villalonga Santana², Arley Pérez Rojas³, \\ Héctor L Ramírez ${ }^{1}$ and Juan José Torres-Labandeira ${ }^{*}$
}

\begin{abstract}
Cyclodextrin glucanotransferase (CGTase, EC 2.4.1.9) is an unique enzyme capable of converting starch and related substrates into cyclodextrins (CDs). In this paper, we report an one step gel purification method of CGTase from Bacillus sp. and later enzyme characterization. The Bacillus sp. strain was isolated from a Colocacia esculenta rizospheric soil sample and the CGTase production was carried out in alkaline medium ( $\mathrm{pH}=10)$. The CGTase purification from the culture supernatant was performed by gel filtration. The enzyme was purified in one step with a recovery of $87.3 \%$ activity and 40 -fold purification for specific enzymatic activity of $2.24 \mathrm{U} / \mathrm{mg}$. Optimal activity was observed at pH 5.0 in citrate-phosphate buffer, and the enzyme retained almost $100 \%$ of its activity between pH 5.5 and 10 after incubation for $1 \mathrm{~h}$ at $4^{\circ} \mathrm{C}$. The enzyme exhibited maximum activity at $55^{\circ} \mathrm{C}$ and showed a $T_{50 \%}$ of $70^{\circ} \mathrm{C}$. The ratio of a:ß:y CD formed by the enzyme was 0.74:1:0.61 for soluble starch and 0.29:1:0.85 for cocoyam starch.
\end{abstract}

Keywords: Cyclodextrins glucanotransferase, Alkalophilic Bacillus sp., Enzyme purification, Enzyme characterization, Cyclodextrin production

\section{Background}

The alkaliphilic bacilli are the best producers of the enzyme cyclodextrin glucanotransferase (CGTase, EC 2.4.1.19). Cyclodextrin glucanotransferase is a multifunctional enzyme which catalyzes four related reactions: cyclizing, coupling, disproportionation, and hydrolysis. By means of the cyclizing activity, CGTase is an unique enzyme capable of converting starch and related substrates into cyclodextrins (CDs) (Jemli et al. 2007).

Cyclodextrins (CDs) are non-reducing cyclic oligosaccharides with the spatial structure of a doughnut. The interior of CDs is hydrophobic and its external surface is hydrophilic. Due to this feature, CDs are able to form inclusion complexes with either organic or inorganic molecules (Abdel et al. 2011). As a result, CDs can change physical and chemical properties of encapsulated

\footnotetext{
* Correspondence: calvarezlorenzo@gmail.com

${ }^{4}$ Department of Pharmacy and Pharmaceutical Technology, University of Santiago de Compostela, Faculty of Pharmacy, Santiago de Compostela 15782, Spain

Full list of author information is available at the end of the article
}

guest compounds. Therefore, CDs are becoming increasingly popular and are extensively used in industries such as pharmaceutical, textile, agriculture, cosmetic, chemical and food, where CDs help to increase the solubility and stability, reduce volatility, and improve the control of the release of drugs, and mask odours and tastes (Atanosova et al. 2008, Hamoudi et al. 2011, Marcon et al. 2009, Sian et al. 2005, Wang et al. 2011).

CGTase is an extracellular, inducible enzyme produced only by microbial cells. The roles of CGTase production in microorganisms are still unclear; however, some researchers believe that starch is converted by CGTase into CDs that cannot be used by other competing organisms. In this way, the CDs can be used as substrate by the CGTase producer.

Most bacterial CGTases mainly produce $\alpha-C D, \beta-C D$ and $\gamma$-CD consisting of six, seven, or eight glucose units, respectively. Thus, CGTase is sometimes classified into three different types ( $\alpha$-, $\beta$ - and $\gamma$-CGTase), depending on the major $C D$ produced. CGTases that synthesize predominantly one type of $\mathrm{CD}$ have great commercial

\section{空}

(c) 2012 Mora et al.; licensee Springer. This is an Open Access article distributed under the terms of the Creative Commons Attribution License (http://creativecommons.org/licenses/by/2.0), which permits unrestricted use, distribution, and reproduction in any medium, provided the original work is properly cited. 
importance, because separation of one type of CDs from a mixture of products is time-consuming, costly and tedious (Jemli et al. 2007). The yields and ratios of $\alpha-, \beta-$ and $\gamma$-CD produced from starch differ depending on the origin of the CGTase and the environmental conditions (Schmid 1989). For this reason, purification and characterization of new CGTases attract a great attention in the CDs production field. Alkalophilic bacilli have received the major attention for industrial applications because of their high activity over a wide range of $\mathrm{pH}$ and temperatures.

The main objective of this study was to purify CGTase from alkalophilic Bacillus species isolated from soil and to characterize some relevant properties of the enzyme.

\section{Result and Discussion}

The CGTase producing strain was identified as Bacillus sp. in previous work Martinez et al. (2012). The CGTase purification from the culture supernatant was performed by gel filtration using Fractogel EMD BioSec(s) as matrix (Figure 1). The active fraction used for the biochemical characterization of the enzyme was located between tube 10 and tube 17, where the enzymatic fraction with the highest purification level was found. In the tube interval from 20 to 30, the concentration in protein (because of the culture medium composition), the cyclodextrin production and the enzymatic activity were maxima, and the enzyme could not be isolated.
The enzyme could be sufficiently purified in one step with a recovery of $87.3 \%$ activity and 40 -fold purification for specific enzymatic activity of $2.24 \mathrm{U} / \mathrm{mg}$ (one unit of enzyme activity refers to the amount of enzyme that catalyzes the production of $1 \mu \mathrm{mol}$ of $\beta-C D$ per minute under the reaction condition) (Table 1). A similar result has been reported for B. agaradhaerens LS-3C CGTase when sufficiently purified using starch adsorption as the sole purification step with a recovery of $50 \%$ activity and 43-fold purification (Martin and Hatti 2002).

Enzyme activity was measured at $55^{\circ} \mathrm{C}$ using the standard assay method by varying the $\mathrm{pH}$ values from 3.0 to 10.5. The optimum $\mathrm{pH}$ of the purified CGTase was 5.0 (Figure 2), which is in agreement with the values reported for purified CGTases from Bacillus sp. 7-12 (Cao et al. 2005) and B. megaterium (Pishtiyski et al. 2008). Most CGTase exhibit optimum $\mathrm{pH}$ ranging from 5.0 to 8.0 (Sian et al. 2005), although the enzyme from Brevibacterium sp. no. 9605 exhibits the highest activity at pH 10.0 (Mori et al. 1994).

The enzyme was then incubated for 60 minutes at $4^{\circ} \mathrm{C}$ under various $\mathrm{pH}$ conditions, prior to the determination of residual activity under standard assay conditions. The enzyme retained $85 \%$ of its initial activity at pHs between 6 and 10.0. At pH 5.0 the activity retained was $70 \%$; below this $\mathrm{pH}$ value a drastic reduction in enzyme activity was observed (Figure 3). When compared to other Bacillus CGTases, a similar behavior was observed

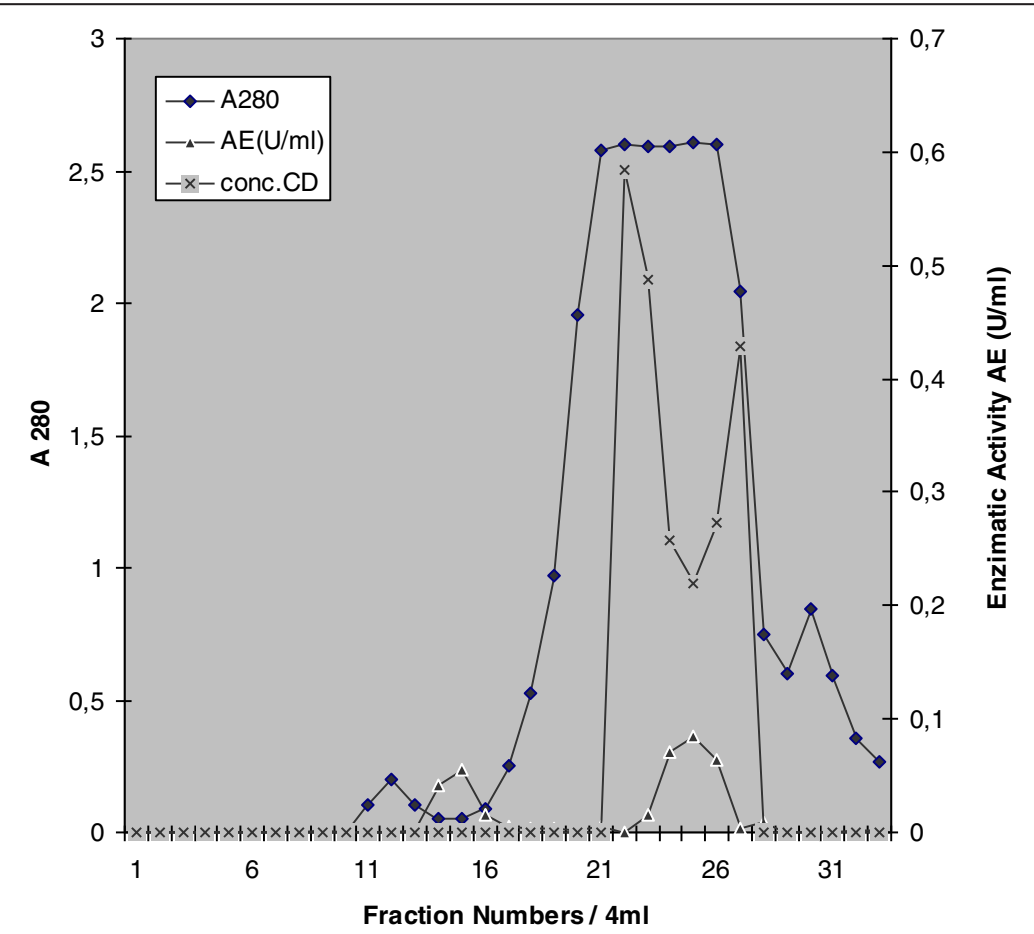

Figure 1 Elution profile of the CGTase from gel filtration chromatography column using Fractogel EMD BioSEC (S). Fraction 10-17 was collected and used for subsequent characterization steps. 
Table 1 Summary of CGTase purification results

\begin{tabular}{|c|c|c|c|c|c|c|}
\hline Steps & $\begin{array}{l}\text { Total volumen } \\
(\mathrm{mL})\end{array}$ & $\begin{array}{c}\text { Protein concentration } \\
(\mathrm{mg} / \mathrm{mL})\end{array}$ & $\begin{array}{c}\text { Enzimatic activity (U/ } \\
\mathrm{mL} \text { ) }\end{array}$ & $\begin{array}{c}\text { Especific activity. (U/ } \\
\text { mg) }\end{array}$ & $\begin{array}{l}\text { Purification } \\
\text { fold }\end{array}$ & $\begin{array}{c}\text { Yield } \\
(\%)\end{array}$ \\
\hline Crude enzyme & 25 & 3.1 & 0.17 & 0.06 & 1 & 100 \\
\hline Concentration & 5 & 15.5 & - & - & - & - \\
\hline $\begin{array}{l}\text { Gel filtration } \\
\text { (Fractogel) }\end{array}$ & 28 & 0.06 & 0.16 & 2.70 & 48.2 & 105.2 \\
\hline Concentration & 4.8 & 0.34 & 0.77 & 2.24 & 40 & 87.3 \\
\hline
\end{tabular}

for $B$. agaradhaerens LS-3C enzyme, which possesses the widest $\mathrm{pH}$ span for stability, namely between $\mathrm{pH}$ 5.411.0 (Martin and Hatti 2002).

The activity of the purified CGTase was measured at different temperatures at $\mathrm{pH}$ 5.0. As can be seen in Figure 4 , the enzyme was optimally active at $55^{\circ} \mathrm{C}$ when soluble starch was used as substrate. Studies done by other researchers on CGTase from B. megaterium (Kitahata et al. 1974), B. macerans IFO 3490 (Kaneko et al. 1990), B. lentus (Sabioni and Park 1992) and B. agaradhaerens (Martin and Hatti 2002) also pointed out $55^{\circ} \mathrm{C}$ as the optimum temperature. Most of the reported Bacillus CGTases shows optimum temperature in the range from 45 to $80^{\circ} \mathrm{C}$ (Martin and Hatti 2002).

The enzyme was stable up to $55^{\circ} \mathrm{C}$ at $\mathrm{pH} 5.0$ for 30 min incubation, retaining almost $100 \%$ activity. However, it lost $15 \%$ of its total activity at around $70^{\circ} \mathrm{C}$ and had $65 \%$ activity at $75^{\circ} \mathrm{C}$. The CGTase was completely inactive at $85^{\circ} \mathrm{C}$ (Figure 5). Thus, the isolated enzyme has higher temperature stability than CGTase from K. pneumoniae AS-22 (Gawande and Patkar 2001) and B. agaradhaerens (Martin and Hatti 2002), both showing maximum stability at $40^{\circ} \mathrm{C}$.

The capability of the purified CGTase to produce CDs was investigated using starches from different sources. Soluble starch appeared to be the best substrate for $\beta$ -

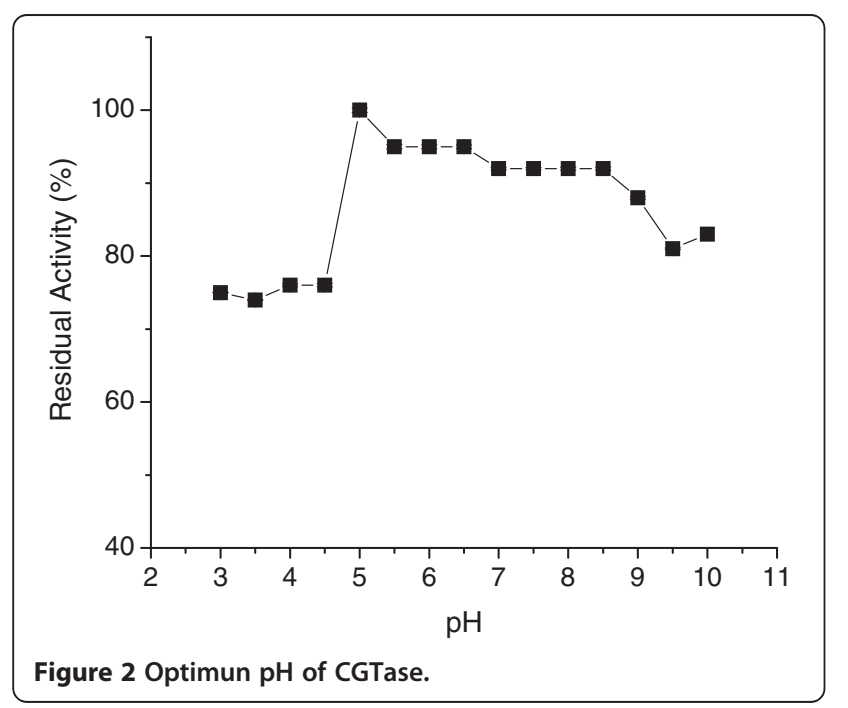

CD production, leading to $\alpha: \beta: \gamma$ production ratio of 0.74:1:0.61 (Figure 6). Cocoyam starch is a non conventional source to produce CDs; nevertheless, it may have interest as substrate of the isolated enzyme since it caused a marked change in the $\alpha: \beta: \gamma$ production ratio, i.e. 0.29:1:0.85, with respect to the soluble starch. Cocoyam starch notably increased the $\gamma$-CD production, which has high market price. The $\alpha: \beta: \gamma$ proportion obtained for cocoyam starch was similar to that reported for alkalophilic Bacillus sp. 7-12 CGTase ( $\alpha: \beta: \gamma=$ $0.26: 1: 0.86)$ with soluble starch after $12 \mathrm{~h}$ of reaction at $60^{\circ} \mathrm{C}, \mathrm{pH} 8.0$ (Cao et al. 2005). These findings confirm that the source of starch is a critical point in the production of CDs, which can be attributed to the differences in the starch granules structure and properties.

\section{Conclusion}

Cyclodextrin glucanotransferase (CGTase) from alkalophilic Bacillus has been successfully purified and effectively used for conversion of starch into cyclodextrin under a wide range of $\mathrm{pH}$ conditions. The enzyme exhibits a good thermostability and shows optimum temperature at $55^{\circ} \mathrm{C}$. Furthermore, it is a good candidate to obtain increased production of $\gamma$-CD production when used cocoyam starch as substrate.

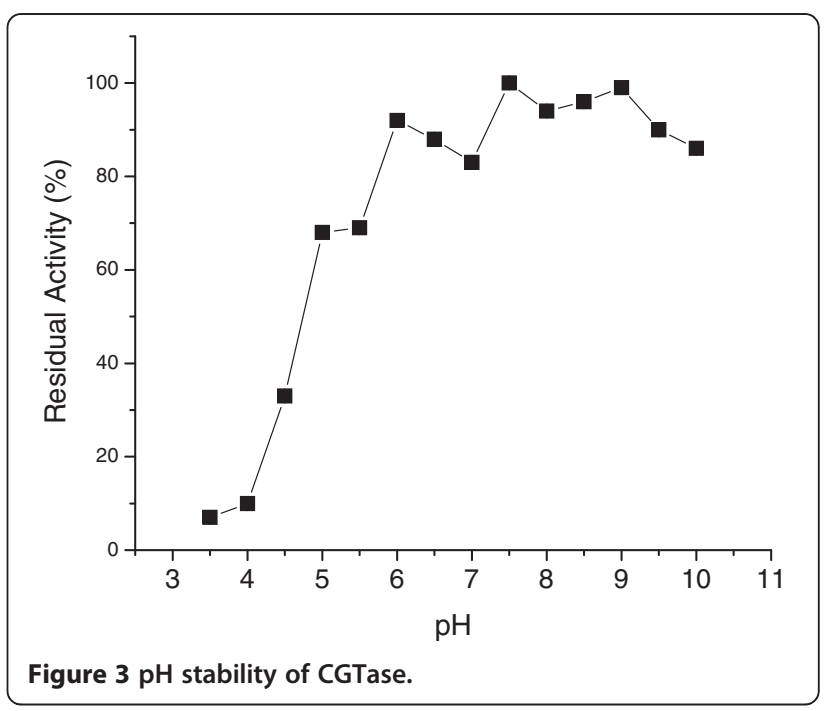




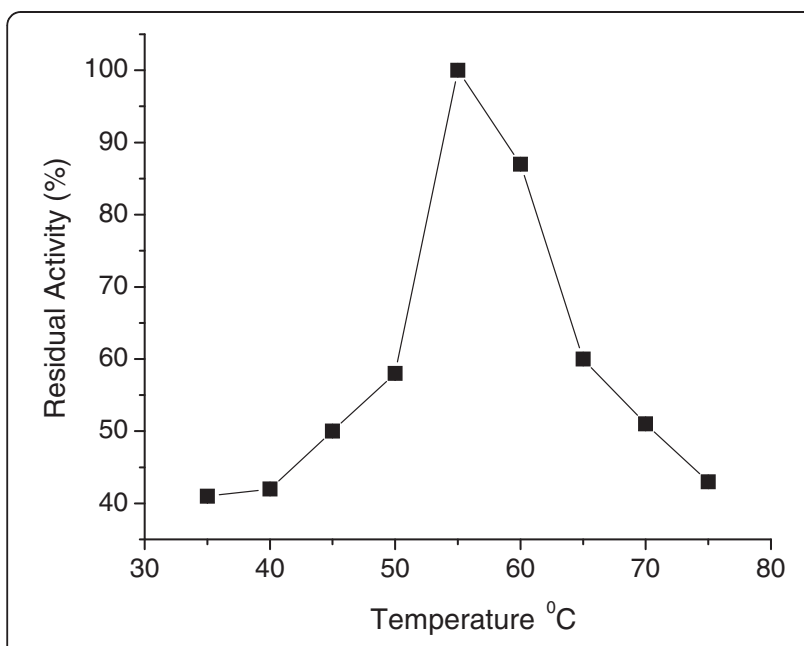

Figure 4 Optimun temperature of CGTase.

\section{Material and Methods}

\section{Materials}

$\alpha$-, $\beta$ - and $\gamma$-Cyclodextrin were purchased from Pharmacia Biotech. Soluble starch, Fractogel EMD BioSec(s), yeast extract and peptone was purchased from Sigma. Cocoyam starch was of industrial grade. Phenolphthalein was purchased from Merck. All other chemicals were of analytical grade.

\section{Screening and Isolation of bacteria}

Bacteria were isolated from Colocacia esculenta rizospheric soil. Samples were suspended in sterile water, serial diluted, and then plated on Horikoshi II agar plate containing $(\mathrm{w} / \mathrm{v}): 1.0 \%$ soluble starch, $0.5 \%$ yeast extract, $0.5 \%$ peptone, $0.1 \% \mathrm{KH}_{2} \mathrm{PO}_{4}$, $0.02 \% \mathrm{MgSO}_{4} .7 \mathrm{H}_{2} \mathrm{O}, 0.02 \%$ phenolphthalein and $1.0 \%$ $\mathrm{Na}_{2} \mathrm{CO}_{3}$ (separately autoclaved). Plates were incubated at $37^{\circ} \mathrm{C}$ for $24 \mathrm{~h}$. Bacterial colonies which produced the

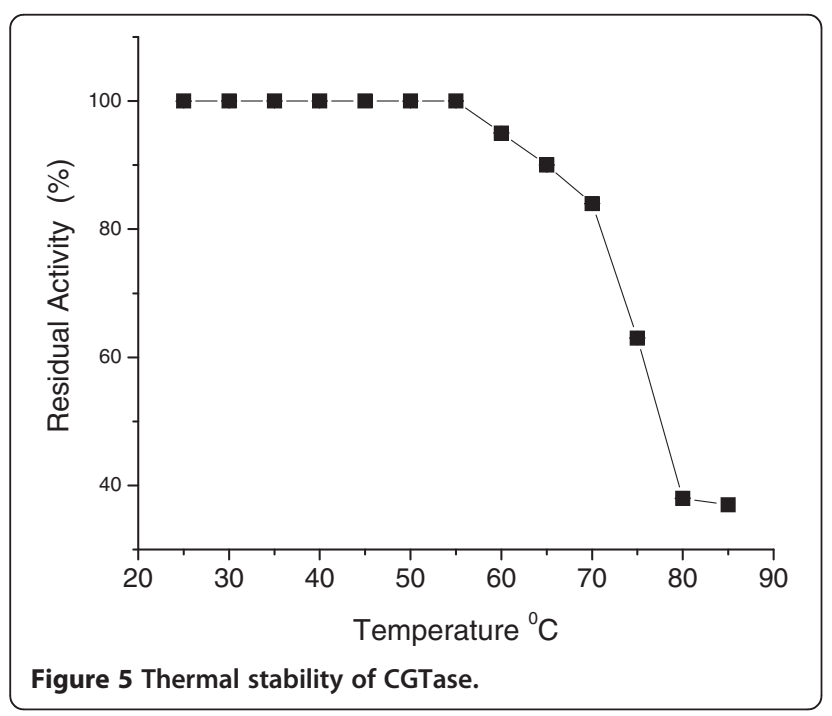

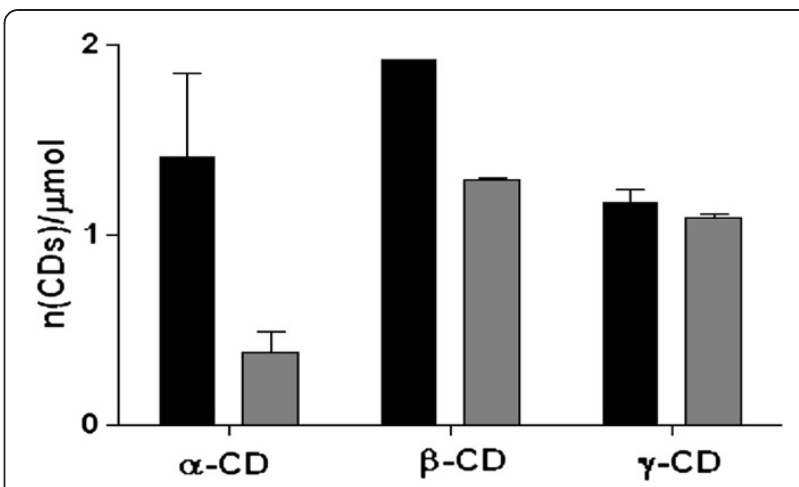

Figure 6 Production of cyclodextrins on soluble (black) and cocoyam starch (gray).

largest clear halo zones were selected for further studies (Illias et al. 2002).

\section{CGTase production and purification}

The selected strain was cultivated in flasks containing $200 \mathrm{~mL}$ of Horikoshi II broth culture medium and incubated at $37^{\circ} \mathrm{C}$ during 48 hours at $200 \mathrm{rpm}$. Cells and insoluble material were removed by centrifugation at 2012 g for $15 \mathrm{~min}$ at $4^{\circ} \mathrm{C}$, and the cell-free supernatant was used as the source of the enzyme. The crude extract $(25 \mathrm{ml})$ was concentrated to a final volume of $5 \mathrm{ml}$ by rotoevaporation to $30^{\circ} \mathrm{C}$. Later, the sample was purified to $4^{\circ} \mathrm{C}$ in chromatographic column of gel filtration $(1.6 \mathrm{X} 60 \mathrm{~cm})$ using Fractogel EMD BioSec(s) as matrix with mobile phase buffer Tris/ $\mathrm{HCl}$ pH 8.0 $20 \mathrm{mM}$. The column was washed with the same buffer at flow rate $60 \mathrm{~mL} / \mathrm{h}$ at fractions of $4 \mathrm{ml}$ was collected. The protein concentration was estimated using the Bradford method (Bradford 1976).

\section{Cyclizing activity of CGTase}

The cyclizing activity of CGTase was determined applying the phenolphthalein method, measuring the production of $\beta-C D$ spectrophotometrically at $550 \mathrm{~nm}$, on the basis of its ability to form a colourness inclusion complex with this dye. Phenolphtalein $(4 \mathrm{mM})$ in ethanol was diluted in $125 \mathrm{mM} \mathrm{Na}_{2} \mathrm{CO}_{3} \mathrm{pH} 11$ just before starting the assay. $2 \%$ Starch in $0.05 \mathrm{M}$ citrate-phosphate buffer $\mathrm{pH} 5.0$ were used as substrate. One unit of CGTase is defined as the amount of enzyme catalyzing the production of $1 \mu \mathrm{mol}$ of $\beta$-CD per minute under the reaction conditions (Goel and Nene 1995).

\section{Optimum $\mathrm{pH}$}

The effect of $\mathrm{pH}$ on CGTase activity was measured in the range from 3.0 to 10.5 , at $55^{\circ} \mathrm{C}$ for 10 minutes using $50 \mathrm{mM}$ citrate-phosphate $(\mathrm{pH} 3.0-7.5), 50 \mathrm{mM}$ Tris- $\mathrm{HCl}$ ( $\mathrm{pH} 8.0-9.0)$ and $50 \mathrm{mM}$ sodium carbonate $(\mathrm{pH} 9.0-11)$ buffers. 


\section{Stability against $\mathrm{pH}$}

Enzyme preparations $(0.57 \mathrm{U})$ were incubated at $4{ }^{\circ} \mathrm{C}$ in $100 \mathrm{mM}$ sodium acetate/acetic acid (pH 3.0-5.5), $100 \mathrm{mM}$ $\mathrm{K}_{2} \mathrm{HPO}_{4} / \mathrm{KH}_{2} \mathrm{PO}_{4}(\mathrm{pH} 6.0-7.5), 100 \mathrm{mM}$ Tris/HCl $(\mathrm{pH}$ 8.0-9.0) and $\mathrm{Na}_{2} \mathrm{CO}_{3} / \mathrm{NaHCO}_{3}$ (pH 9.5-11.5) buffers. Aliquots were removed after 60 minutes of incubation, diluted in $0.1 \mathrm{M} \mathrm{K}_{2} \mathrm{HPO}_{4} / \mathrm{KH}_{2} \mathrm{PO}_{4}$ buffer ( $\mathrm{pH}$ 7.0) and assayed for cyclizing activity of CGTase.

\section{Optimum temperature}

The effect of temperature on CGTase activity was evaluated in the range of $35-75^{\circ} \mathrm{C}$ in $50 \mathrm{mM}$ citrate phosphate (pH 5.0) buffer. After incubation for 10 minutes, the cyclizing activity was measured.

\section{Thermostability}

Enzyme preparations $(0.57 \mathrm{U})$ were incubated at different temperatures between $25^{\circ} \mathrm{C}$ and $85^{\circ} \mathrm{C}$ in $50 \mathrm{mM}$ sodium citrate phosphate buffer, $\mathrm{pH}$ 5.0. Aliquots were removed after 30 minutes incubation, chilled quickly, and assayed for cyclizing activity.

\section{Determination of CDs concentration}

The enzyme $(0.27 \mathrm{mg} / \mathrm{mL})$ was incubated at $55^{\circ} \mathrm{C}$ for 60 minutes with $1.5 \%$ starch in $50 \mathrm{mM}$ citrate phosphate buffer $(\mathrm{pH}=5.0)$. The concentration of the various $\mathrm{CDs}$ produced by the action of the purified CGTase on soluble and cocoyam starch was colorimetrically determined. The concentration of $\alpha-C D$ was assayed by the decrease in absorbance at $507 \mathrm{~nm}$ due to the formation of inclusion complexes with methyl orange (Higuti et al. 2004). The concentration of $\beta-C D$ was determined according to the method described above (Goel and Nene 1995). The concentration of $\gamma$-CD was quantified by measuring the absorbance at $630 \mathrm{~nm}$ due to the formation of inclusion complexes with bromocresol green (Kato and Horikoshi 1984).

All experiments were carried out in triplicate under identical conditions.

\section{Abbreviations \\ CGTase: Cyclodextrin glucanotransferase; CDs: Cyclodextrins.}

\section{Competing interests}

The authors declare that they have no competing interests.

\section{Author's contributions}

These authors: MMMM, RVS, JJT-L have made substantial contributions to conception and design, or acquisition of data, or analysis and interpretation of data. These authors: KHS, APR, HLR have been involved in drafting the manuscript or revising it critically for important intellectual content. All authors read and approved the final manuscript.

\section{Acknowledgements}

This research was supported by the International Foundation for Science, Stockholm, Sweden, and the Organization for the Prohibition of Chemical Weapons, The Hague, The Netherlands, through a Grant to H. Ramirez (Grant F/3004-67).

\section{Author details}

${ }^{1}$ Center for Enzyme Technology, University of Matanzas, Matanzas, C.P. 44740, Cuba. ${ }^{2}$ Department of Analytical Chemistry, Faculty of Chemistry, Complutense University of Madrid, Madrid, Spain. ${ }^{3}$ Center for Environmental Studies, University of Matanzas, Matanzas, C.P. 44740, Cuba. ${ }^{4}$ Department of Pharmacy and Pharmaceutical Technology, University of Santiago de Compostela, Faculty of Pharmacy, Santiago de Compostela 15782, Spain.

Received: 10 October 2012 Accepted: 30 November 2012 Published: 12 December 2012

\section{References}

Jemli S, Messaoud E, Ayadi-Zouari D, Naili B, Khemakhem B, Bejar S (2007) A Bcyclodextrin glycosyltransferase from a newly isolated Paenibacillus pabuli US132 strain: Purification, properties and potential use in bread-making. Biochem Eng J 34:44-50

Abdel M, El H, Abdel A (2011) Biosynthesis of cyclodextrin glucosyltransferase by the free and immobilized cells of Bacillus cereus NRC7 in batch and continuous cultures. J Appl Microbiol 111:1129-1137

Atanosova N, Petrova P, Ivanova V (2008) Isolation of novel alkaliphilic bacillus strains for cyclodextrin glucanotransferase production. Appl Biochem Biotechnol 149:155-167

Hamoudi M, Fattal E, Gueutina C, Nicolas V, Bochota A (2011) Beads made of cyclodextrin and oil for the oral delivery of lipophilic drugs: In vitro studies in simulated gastro-intestinal fluids. Int J Pharm 416:507-514

Marcon F, Mathiron D, Pilard S, Lemaire-Hurtel A, Dubaele J, Djedaini-Pilard F (2009) Development and formulation of a $0.2 \%$ oral solution of midazolam containing $\gamma$-cyclodextrin. Int J Pharm 379:244-250

Sian H, Said M, Hassan O, Kamaruddin K, Ismail A, Rahman R (2005) Purification and characterization of cyclodextrin glucanotransferase from alkalophilic Bacillus sp. G1. Process Biochem 40:1101-1111

Wang J, Cao Y, Sun B, Wang C (2011) Physicochemical and release characterization of garlic oil- $\beta$-cyclodextrin inclusion complexes. Food Chem 127:1680-1685

Schmid G (1989) Cyclodextrin glycosyltransferase production: yield enhancement by overexpression of cloned genes. Trends Biotechnol 7:244-248

Martinez MM, Hernandez K, Berrios G, Villalonga R, Ramirez HL, Cabrera G (2012), http://blast.ncbi.nlm.nih.gov/. Bacillus: JQ688043

Martins R, Hatti R (2002) A new cyclodextrin glucanotransferase from an alkaliphilic Bacillus agaradhaerens isolate: purification and characterization. Enz Microb Tech 30:116-124

Cao X, Jin Z, Wang X, Chen F (2005) A novel cyclodextrin glycosyltransferase from an alkalophilic Bacillus species: purification and characterization. Food Res Int 38:309-314

Pishtiyski I, Popota V, Zhekova B (2008) Characterization of Cyclodextrin Glucanotransferase produced by Bacillus megaterium. Appl Biochem Biotechnol 144:263-272

Mori S, Hirose S, Oya T, Kitahata S (1994) Purification and properties of cyclodextrin glucanotrasferase from Brevibacterium sp. no. 9605. Biosc Biotech Biochem 58:1968-1972

Kitahata S, Tsuyama N, Okada S (1974) Purification and some properties of cyclodextrin glycosyltransferase from a strain of Bacillus species. Agric Biol Chem 38:387-393

Kaneko T, Yoshida M, Yamamoto M, Nakamura N, Horikoshi K (1990) Production of cyclodextrins by simultaneous actions of two CGTases from three strains of Bacillus. Starch 42:277-281

Sabioni JG, Park YK (1992) Cyclodextrin glycosyltransferase production by alkalophilic Bacillus lentus. Rev Microbiol 23:128-132

Gawande B, Patkar A (2001) Alpha-cyclodextrin production using cyclodextrin glycosyltransferase from Klebsiella pneumoniae AS-22. Starch 53:75-83

Illias R, Siew T, Aini N (2002) Cyclodextrin Glucanotransferase Producing Alkalophilic Bacillus sp. G1: its Cultural Condition and Partial Characterization of the Enzyme. Pakistan J Biol Sci 5:688-692

Bradford MM (1976) A rapid and sensitive for the quantitation of microgram quantitites of protein utilizing the principle of protein-dye binding. Anal Biochem 72:248-254

Goel A, Nene S (1995) Modifications in the phenolphtalein method for spectrophotometric estimation of beta cyclodextrin

Starch 47:399-400 
Higuti I, Silva P, Papp V, Okiyama M, Alves de Andrade E, Marcondes A, Nascimento A (2004) Colorimetric determination of $a$ and $\beta$-cyclodextrins and studies on optimization of CGTase production from B. firmus using factorial designs. Braz Arch Biol Technol 47:837-841

Kato T, Horikoshi K (1984) Colorimetric determination of $y$-cyclodextrin. Anal Chem 56:1738-1740

doi:10.1186/2193-1801-1-61

Cite this article as: Mora et al:: Partial purification and properties of cyclodextrin glycosiltransferase (CGTase) from alkalophilic Bacillus species. SpringerPlus 2012 1:61.

Submit your manuscript to a SpringerOpen ${ }^{\circ}$ journal and benefit from:

- Convenient online submission

- Rigorous peer review

- Immediate publication on acceptance

- Open access: articles freely available online

- High visibility within the field

- Retaining the copyright to your article

Submit your next manuscript at $>$ springeropen.com 